\title{
FUTURE RESEARCH CHALLENGES FOR A COMPUTER-BASED INTERPRETATIVE 3D RECONSTRUCTION OF CULTURAL HERITAGE - A GERMAN COMMUNITY'S VIEW
}

\author{
S. Münster ${ }^{1 *}$; P. Kuroczyński ${ }^{2}$, M. Pfarr-Harfst ${ }^{3}$, M. Grellert ${ }^{4}$, D. Lengyel ${ }^{5}$
}

[1] Media Center, Dresden University of Technology, Dresden, Germany - sander.muenster@tu-dresden.de

[2] Herder Institute for Historical Research on East Central Europe, Marburg, Germany - piotr.kuroczynski@herder-institut.de

[3] Unit Digital Design, Technische Universität Darmstadt - pfarr@dg.tu-darmstadt.de

[4] Unit Digital Design, Technische Universität Darmstadt - grellert@dg.tu-darmstadt.de

[5] Chair for Visualisation, Brandenburg University of Technology - lengyel@tu-cottbus.de

KEY WORDS: Virtual 3D reconstruction, Perspectives, Survey, Research agenda

\begin{abstract}
:
The workgroup for Digital Reconstruction of the Digital Humanities in the German-speaking area association (Digital Humanities im deutschsprachigen Raum e.V.) was founded in 2014 as cross-disciplinary scientific society dealing with all aspects of digital reconstruction of cultural heritage and currently involves more than 40 German researchers. Moreover, the workgroup is dedicated to synchronise and foster methodological research for these topics. As one preliminary result a memorandum was created to name urgent research challenges and prospects in a condensed way and assemble a research agenda which could propose demands for further research and development activities within the next years. The version presented within this paper was originally created as a contribution to the so-called agenda development process initiated by the German Federal Ministry of Education and Research (BMBF) in 2014 and has been amended during a joint meeting of the digital reconstruction workgroup in November 2014.
\end{abstract}

\section{INTRODUCTION}

For more than 3 decades, digital 3D reconstructions of cultural heritage objects have been carried out on many projects. As an overall consequence, challenges have changed significantly during this time and many new research demands for further methodological, technical and practical development have emerged. Our main interest is to identify urgent research challenges and prospects and assemble a research agenda which could propose demands for further research and development activities within the next years.

The first version of this research agenda was originally created as a contribution to the so-called agenda development process initiated by the German Federal Ministry of Education and Research (BMBF) in 2014. It was aimed at identifying upcoming research topics and funding needs especially from the point of view of a German community dealing with digital reconstruction (Arbeitsgruppe Digitale Rekonstruktion des Digital Humanities im deutschsprachigen Raum e.V., 2014). It contained contributions submitted by 13 researchers from different disciplinary backgrounds and perspectives on digital reconstruction. This process was initiated by a paper which was circulated in summer 2014. In addition, different outcomes from a joint meeting of the digital reconstruction workgroup in November 2014 (Grellert et al., 2015), which focused on a state-of-the-art analysis, were included in an amended version. They are presented in this paper. Even if the research agenda was created by a German scholarly community focusing on German perspectives, many of the topics addressed may also be relevant to an international community.

\subsection{Classification of digital reconstruction}

Computer-based, i.e. digital 3D reconstructions have increasingly become more important for sustaining conservation, research and broad accessibility of cultural heritage as knowledge carriers, research tools and means of representation. Concerning digital reconstruction, the focus is put on the creation of a spatial, temporal and semantic virtual model. Main differences refer to the kind of object of assessment in terms of material and immaterial objects (e.g. usages or digital data). Furthermore, in regard to the question of how to proceed, the difference between the reconstruction of objects which are no longer existent or which have never been realised (e.g. the current status of plans which have never been realised) and the digitalisation of objects which are still existent is essential (De Francesco and D'Andrea, 2008). While a digitalisation describes the technological transfer of an object to a digital sat (e.g. by means of a semi-automatic modelling with the help of laser scans or photogrammetric technology), a digital reconstruction process includes the necessity for human interpretation of data.

\subsection{State-of-the-art}

In practice, concerning establishment, digital reconstructions have been commonly used both in the academic and commercial field. Currently, digital reconstructions are mainly carried out in one single context in relation to specific usages by interdisciplinary workgroups and by using expert technologies. Especially in regard to this background, it has turned out to be difficult that there are so many standards and guidelines as well as rules for dealing with historical contents (Beacham et al., 2006; Bendicho, 2011; Kiouss et al., 2011; Pfarr, 2009; Sürül et al., 2003) which have only been of limited practical relevance (Kuroczyński et al., 2014; Münster and Köhler, 2012). In contrast, the concept of metadata used as an approach to classify and describe historical information has been established to a large extent. Even if in the meantime one of this schemas has gained a certain popularity with CIDOC-CRM (Doerr, 2003) as reference ontology (in terms of a generic concept of knowledge structure) in archaeology and museology, existing standards of metadata and their implementation are considered as being highly heterogeneous (Felicetti and Lorenzini, 2011; Ronzino et 
al., 2011; Ronzino et al., 2013). Current approaches on sustainable documentation of the creative process of digital reconstructions have not yet been sufficiently established in practice (Bentkowska-Kafel et al., 2012) despite diverse and innovative concepts (Niccolucci, 2012; Pfarr-Harfst, 2011). An international science community has been shaped by actors from Southern Europe, Great Britain and the US. It mainly comprises perspectives on archaeology and cultural heritage conservation (European Commission, 2011; Foni et al., 2010; Münster et al., in print). A multiplicity of actors from science, economy and education deal with the topic of digital reconstruction in the German-speaking area. Established panels have not yet been set up and a national as well as international networks required for a scientific discourse across disciplines and usages have not yet been established (Pfarr-Harfst, in print).

\subsection{Actors and funding environment in Germany}

A German research environment on digital humanities to which also belongs digital reconstruction of cultural heritage is traditionally strongly affected by dealing with texts and images. However, national priorities on dealing with cultural heritage focus on the development and museal presentations of collections. In contrast, topics of digital 3D reconstructions of cultural heritage have been much less institutionally anchored. Even if many professors out of several disciplines put their work and research focus on the field of digital reconstructions, in Germany no professorship or academic institute is specifically arranged to address these topics in particular yet. A circle of actors is characterised by small workgroups or individual actors. However, they come - as exemplified in Figure 1 by the members of the digital reconstruction workgroup of the Digital Humanities in the German-speaking area association (Digital Humanities im deutschsprachigen Raum e.V.) - from a multiplicity of different institutions and all academic career stages.

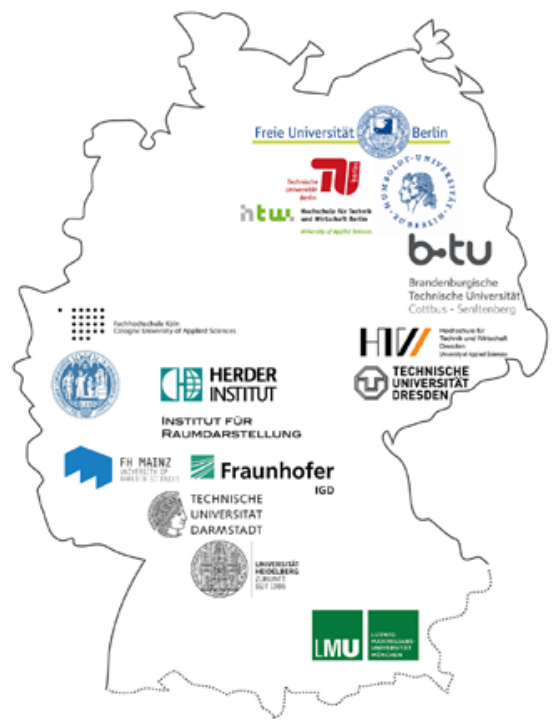

Figure 1 - Institutions of the members of the digital reconstruction workgroup of the Digital Humanities in the German-speaking area association (Digital Humanities im deutschsprachigen Raum e.V.).

Up to now, digital reconstruction projects carried out in Germany have been funded by a heterogeneous field of funding institutions and funding objectives. This includes regional and local funding schemes and research funding on a national level. With a German national funding environment in mind, the German Federal Ministry of Education and Research has lately addressed the assessment of humanities-related questions by means of digital tools ("eHumanities") and the scientific preparation of collections ("The language of objects"). Funded by the German Federal Ministry of Education and Research, a current project is being carried out to assess the space-related placing of inscriptions. ${ }^{1}$ Furthermore, the structure of a virtual research environment used for web-based documentation and demonstration of semantic 3D datasets of destroyed architecture in Eastern Prussia (Kuroczyński et al., submitted paper) have been assessed thanks to the funding of the Leibnitz Association. The documentation and visualisation of archaeological contents have been examined with the help of the German Research Foundation (DFG). ${ }^{2}$ On a European level, the Reflective 6 \& 7 advertisements carried out in the scope of the Horizon Programme 2020 address questions asking for comprehensive standards and formats used for cultural-historical information. ${ }^{3}$ Similar to guidelines issued for previous ICT programmes, this advertisement mainly aims at the development of technology. In contrast, EU funds used for a creative Europe focus on specific cases of usage. ${ }^{4}$ It has only restrictively been taken into consideration that digital reconstructions are complex sociotechnical usages which in the meantime have been widely used in the academic environment and museums, media studies and tourism with the help of a current funding environment. For this reason, a number of funding needs exceeding a pure technological development or single usages have come up.

\section{PROPOSITIONS AND IDEAS ON RELEVANT TOPICS AND QUESTIONS}

A number of current tasks of digital humanities in the Germanspeaking area were described in the scope of a discussion paper issued by the management board of the Digital Humanities in the German-speaking area association and published at the annual conference 2014 (Vorstand des Verbandes Digital Humanities im deutschsprachigen Raum, 2014). In addition, a number of specific challenges have emerged in the context of digital reconstruction.

\subsection{Assessment of the scope of digital reconstruction}

Digital reconstructions do not just use technologies available in the field of information technology used for the development of humanities-related questions but they additionally incorporate a multiplicity of different disciplinary perspectives and contexts of usage. Besides archaeology and different tasks of cultural heritage conservation as main focuses of European funding, specific scenarios of art and architectural history, cultural studies, monument preservation, historical building research and museology are relevant to the German research environment (Burwitz et al., 2012; Riedel et al., 2011). Connected to this is the need to record and systematise research and usage approaches of digital reconstruction and related properties, potentials and fields of usage (Pfarr-Harfst, 2013). In addition to

${ }^{1}$ Inschriften im Bezugssystem des Raumes.

http://www.spatialhumanities.de/ibr/startseite.html (12.1.2015).

${ }^{2}$ OpenInfRA - Ein webbasiertes Informationssystem zur Dokumentation und Publikation archäologischer Forschungsprojekte. http://www.tu-cottbus.de/projekte/de/openinfra/ (12.1.2015).

${ }^{3}$ Reflective societies: Cultural Heritage and European Identities. http://ec.europa.eu/research/participants/portal/desktop/en/opportuni ties/h2020/calls/h2020-reflective-7-2014.html (12.1.2015).

${ }^{4}$ Creative Europe Program. http://ec.europa.eu/programmes/creativeeurope/index_en.htm (12.1.2015). 
the documentation of spatial-related knowledge (as spatial humanities domain), they include the description of historical objects, the research of historical preparation processes (e.g. historical approaches and craftsmen approaches of planning), contextualisation and assessment of the consistency of sources, classification of objects and subsequent establishment of thesauri and the identification of archetypal characteristics (e.g. craftsmen specifications). Moreover, different usages exist beyond a reference made to concrete historical objects, such as the exploration of a scope with the help of architectural systems and approaches of procedural modelling of hypothetical buildings which are to be erected (Havemann and Wagener, in print; Ling et al., 2007). The recording of good practice examples as well as research and development projects refer to tasks which have to be taken up in a research agenda as was developed for cultural heritage (Arnold and Geser, 2008) research and archaeology (Gibbons, 2012).

\subsection{Digital reconstruction between research and practical usage}

Unlike hardly any other field of digital humanities, digital reconstructions are a cross-sectional area between research and practical use. Respectively, in addition to questions of research and science, there are diverse usages beyond the academic one e.g. in the context of teaching, museal presentation, virtual tourism, cultural heritage management or popular media (Grellert, 2007; Kuroczyński, 2012; Münster, 2011). Therefore, transfer and exchange between research and practical use is essential, e.g. concerning used technologies, standards and schemas, strategies and quality standards. Furthermore, an assessment of practice-oriented aspects beyond questions of humanities, such as creativity conducive to learning, usability or sustainable business models.

\subsection{Establishing virtual models and visual results as topics of scientific discourse}

Other than in text-related disciplines, knowledge is mainly gained by the creation of a virtual model and its digital, in most cases, visual demonstration in the case of digital reconstruction. Moreover, contributions of different authors and a multiplicity of intuitive decisions are included in such media which are based on know-how (Münster and Prechtel, 2014). So far, both an academic culture and concrete mechanisms have not yet been established to make digital models and generated images scientifically linkable and able to discuss. This includes questions on the access and evaluation of models and images to make authorship transparent as well as references between reconstruction and (explainable) fundamental knowledge such as sources. This also comprises the capacity to quote parts or areas in models and images and the modification of such media by others. In addition to a number of technical requirements described in the following paragraph, the development of approaches on the documentation of processes and their results and the capacity of making a model logic transparent are derived (Günther, 2001; Hoppe, 2001) - e.g. within the meaning of comprehensive reference ontologies and custom-designed domain ontologies (Hauck and Kuroczyński, 2014; Homann, 2011; Ronzino, 2015).

\subsection{Securing sustainability}

It can be seen that in most cases new technologies and trends have quickly been picked up in single projects carried out on digital reconstruction (Münster et al., in print). However, they have just been made transparent mainly via publications issued for a (professional) public in academic contexts. In addition to the aspects of interoperability and long-term availability of datasets, competencies and procedure models to improve accessibility and sustainability of the assessment and mapping of the projects carried out on digital reconstructions of all provenances and the inclusion of established actors, such as libraries, commercial platforms or research infrastructures are essential in making information in this regard available.

\subsection{Establishing digital infrastructures for digital reconstructions}

Beyond buildings, originals of important archaeological objects or objects of art history such as finds or sculptures are often detached from their original context (e.g. in collections, museums etc.). Thus, they can only be assessed, analysed and evaluated spatially in an isolated way. In contrast, virtual objects can not only be re-contextualised by taking into consideration a different probability of the reconstruction hypothesis but also with references between single objects in mind (Laufer et al., 2011; Lengyel and Toulouse, 2011b, c). ${ }^{1}$ They can be linked in a differentiated way to (source) materials and information on projects (Raspe and Schelbert, 2009). For a long time, the focus of a multiplicity of European projects (e.g. EPOCH, 3D COFORM, CARARE, 3D ICONS) has been put on the recording and storage of historical sources of different kinds, digital research artefacts and results as well as allocated metadata, paradata and contextual data (D'Andrea and Fernie, 2013). However, especially in the German-speaking area, requirements put on digital reconstruction have only been reflected insufficiently beyond archaeology and architectural history (Drewello et al., 2010) in research infrastructures. ${ }^{2}$ Despite its name, the DARIAH Geobrowser and the Europeana 4D interface are mainly aimed at a two-dimensional mapping of objects. Specific requirements of digital reconstructions are mainly the space- and time-related classification and identification of created digital models and related (source) materials (e.g. by means of word-wide valid unified resource identifiers) and their relationships. Moreover, digital reconstructions have been developed by using a multiplicity of different technologies from domains such as GIS, VR, CAD and BIM or CityEngines which are only a little compatible (Münster and Prechtel, 2014). They are not convertible without loss. Related tasks are likewise assessment, development and spreading of technologies and strategies on interoperability of data - e.g. on conversion without loss or on data exchange in proprietary formats. Furthermore, with linkage in mind, data viewers which are easy to operate have been used for the illustration of 3D datasets. Therefore, there are special requirements in regard to interactivity and simulation quality of materiality and weathering. Furthermore, tools and mechanisms for semantic annotation and modification of existing reconstructions, for the inclusion of alternative hypotheses or for versioning are required. According to the complex requirements the Semantic Web and WebGL technologies seem to be highly promising. Research on and implementation of documentation and visualisation standards within the

\footnotetext{
${ }^{1}$ Berliner Skulpturennetzwerk.

http://de.wikipedia.org/wiki/Berliner_Skulpturennetzwerk (12.1.2015).

${ }^{2}$ IANUS - Forschungsdatenzentrum Archäologie \&

Altertumswissenschaften. http://www.dainst.org/de/project/ianus-

forschungsdatenzentrum-arch\%C3\%A4ologie-

altertumswissenschaften?ft=all (12.1.2015).
} 
community of digital hypothetical 3D reconstruction is a prerequisite. Using above-mentioned open source technologies for web-based description and publishing of the 3D content, in particular developing a domain related ontology (OWL DL), storing the whole process chain and results in a human- and machine-readable schema (XML-Format), linkage with existing controlled vocabularies and authority files (e.g. Getty AAT, etc.), establishing a Graph Database (RDF-Triple-Store) with a SPARQL Endpoint, provides new quality comprehensibility and sustainability within Linked (Open) Data infrastructure (Kuroczyński et al., 2015).

\subsection{Developing of competencies in dealing with images and digital reconstruction}

Especially in the humanistic approach, affinity and competence regarding digital research methods have only been little developed (Albrecht, 2013). Similar to digital humanities altogether (Vorstand des Verbandes Digital Humanities im deutschsprachigen Raum, 2014), method-related development of knowledge and competencies of researchers and users in practice (e.g. curators) concerning a production, evaluation and usage of digital reconstructions pose a main challenge (Kröber and Münster, 2014). Thus, scientific findings in archaeology and construction research are in most cases incomplete. The level of accurateness of knowledge extends from authentic finds to scientific hypotheses, which can also be contradictory. Beside a gradual difference between secure and insecure reconstruction, there is also a coexistence of different alternatives. It is a special strength of virtual models to take up this lack of definition and to be able to make it available in form of special visualisations on scientific discussions and mediation (Grellert and Haas, in print; Lengyel and Toulouse, 2011a, c, 2013). Connected with it is the challenge posed on users to develop the competence of methods and usage for dealing with synthetically produced images and models in both scientific and popular contexts. This includes a conscience concerning tentativeness, the nature of the hypotheses of incorporated knowledge and an evaluation competence in regard to fields of usage and production processes.

\subsection{Assessment of digital reconstructions as socio-technical systems}

So far, topics related to digital reconstruction have mainly emerged in the German research and funding environment with technological development and a specific reference to objects in mind. In contrast, widely excluded has been an examination of socio-technical aspects. In addition to the needs already described, research and development of suitable workflows and strategies used for the creation of digital reconstructions is a main task. In addition to ideas on the organisation of working processes and on interdisciplinary communication and co-operation (Münster, 2013) given by the innovation and project management, innovative approaches such as agile development methods of information technology (Baldwin and Flaten, 2012), have promised added values in practice and in science.

\subsection{Establishing digital reconstruction in the German digital humanities area}

Currently, the landscape of digital reconstruction in Germany includes a multiplicity of actors from different backgrounds. So far, they have been insufficiently linked and organised. Hence, the need of joint platforms for an exchange and the establishment of digital reconstruction in the canon of digital humanities as well as the necessity of support of networking activities have been derived. While single references to topics of digital reconstruction such as museology and archaeology have been taken up by panels and workgroups anchored in these fields, structures and institutions of a scientific and practical development have been missing in the German-speaking area. In this regard, a first step is the workgroup for digital Reconstruction of the Digital Humanities in the Germanspeaking area association founded in $2014 .^{1}$

\section{CONCLUSION}

While the usage of digital reconstruction techniques in the context of cultural heritage has been widely explored by prototypic projects and methodological perspectives, current challenges aim at a research and development of sustainable and practicable approaches to access wider scientific communities (and to establish and ensure scholarly standards in this domain) and audiences as well as to enhance interoperability. This includes aspects such as widely interoperable documentation and classification strategies and schemes, an overarching systematisation and cataloguing of projects and the creation of objects as well as strategies and technologies for an exchange between different technological domains and approaches of usage. Moreover, digital reconstructions are socio-technical systems embedded in complex usage scenarios. Due to these reasons, it is crucial to determine research and usage scenarios as well as additional values of digital reconstruction and identify best practice cases. Thus, an identification of both, user and non-user-needs and motivations as well as the education and competency development of researchers, producers and recipients are essential. In addition, the research for and usage of digital reconstruction technologies have to be established and positioned as an important field of usage within a digital humanities scientific community, digital infrastructures as well as within a funding community.

\section{ACKNOWLEDGEMENTS}

This paper is originally based on a joint contribution to the agenda development process of the German Federal Ministry of Education and Research (BMBF) in 2014. The authors would like to thank Henning Burwitz, Frank Henze, Stephan Hoppe, Cindy Kröber, Nikolas Prechtel, Georg Schelbert, Catherine Toulouse and Markus Wacker for their valuable ideas, comments and feedbacks. Moreover, the authors like to thank all participants of the joint meeting of the digital reconstruction workgroup which met in November 2014 to develop additional ideas and perspectives.

\section{REFERENCES}

Albrecht, S., 2013. Scholars` Adoption of E-Science Practices: (Preliminary) Results from a Qualitative Study of Network and Other Influencing Factors., XXXIII. Sunbelt Social Networks Conference of the International Network for Social Network Analysis (INSNA), 21-26 May 2013, Hamburg.

\footnotetext{
${ }^{1}$ Arbeitsgruppe Digitale Rekonstruktion des Digital Humanities im deutschsprachigen Raum e.V. http://www.digitalerekonstruktion.info/ (12.1.2015).
} 
Arbeitsgruppe Digitale Rekonstruktion des Digital Humanities im deutschsprachigen Raum e.V., 2014. Aktuelle Herausforderungen im Kontext digitaler Rekonstruktion (Beitrag zum BMBF-Agendaprozess).

Arnold, D., Geser, G., 2008. EPOCH Research Agenda - Final Report, Brighton.

Baldwin, T.D., Flaten, A.R., 2012. Adapting the Agile Process to Digital Reconstructions of the Temple of Apollo at Delphi, in: Zhou, M., Romanowska, I., Wu, Z., Xu, P., Verhagen, P. (Eds.), Revive the Past. Computer Applications and Quantitative Methods in Archaeology (CAA). Proceedings of the 39th International Conference. Pallas Publications, Amsterdam pp. 30-37.

Beacham, R., Denard, H., Niccolucci, F., 2006. An Introduction to the London Charter, in: Ioannides, M., Arnold, D., Niccolucci, F., Mania, K. (Eds.), Papers from the Joint Event CIPA/VAST/EG/EuroMed Event, pp. 263-269.

Bendicho, V.M.L.-M., 2011. The principles of the Seville Charter XXIII CIPA Symposium - Proceedings.

Bentkowska-Kafel, A., Denard, H., Baker, D., 2012. Paradata and Transparency in Virtual Heritage. Ashgate, Burlington.

Burwitz, H., Henze, F., Riedel, A., 2012. Alles 3D? - Über die Nutzung aktueller Aufnahmetechnik in der archäologischen Bauforschung, in: Faulstich, E.I. (Ed.), Dokumentation und Innovation bei der Erfassung von Kulturgütern II, Schriften des Bundesverbands freiberuflicher Kulturwissenschaftler, Band 5, Online-Publikation der BfK-Fachtagung 2012, Würzburg.

D’Andrea, A., Fernie, K., 2013. CARARE 2.0: a metadata schema for 3D Cultural, The proceedings of the 1st International Conference Digital Heritage 2013, Marseille http://3dicons-project.eu/eng/Media/Files/CARARE-2.0-ametadata-schema-for-3D-Cultural-Objects (09.07.2015).

De Francesco, G., D’Andrea, A., 2008. Standards and Guidelines for Quality Digital Cultural Three-Dimensional Content Creation, in: Ioannides, M., Addison, A., Georgopoulos, A., Kalisperis, L. (Eds.), Digital Heritage: Proceedings of the 14th International Conference on Virtual Systems and Multimedia. Project Papers. Archaeolingua, Budapest, pp. 229-233.

Doerr, M., 2003. The CIDOC CRM - An Ontological Approach to Semantic Interoperability of Metadata. AI Magazine 24.

Drewello, R., Freitag, B., Schlieder, C., 2010. Neues Werkzeug für alte Gemäuer. DFG Forschung Magazin 3, 10-14.

European Commission, 2011. Survey and outcomes of cultural heritage research projects supported in the context of EU environmental research programmes. From 5th to 7th Framework Programme. European Commision, Brussels.

Felicetti, A., Lorenzini, M., 2011. Metadata and tools for integration and preservation of cultural heritage 3D information, XXIII CIPA Symposium - Proceedings.

Foni, A.E., Papagiannakis, G., Magnenat-Thalmann, N., 2010. A taxonomy of visualization strategies for cultural heritage applications. Journal on Computing and Cultural Heritage 3, 121.

Gibbons, G., 2012. Visualisation in Archaeology Project. Final Report. English Heritage, o. Ort.

Grellert, M., 2007. Immaterielle Zeugnisse - Synagogen in Deutschland: Potentiale digitaler Technologien für das Erinnern zerstörter Architektur (Dissertation). transcript Verlag, Bielefeld.

Grellert, M., Haas, F., in print. Between Science and Illusion. Virtual reconstructions in Darmstadt University - The Dresden Castle, in: Hoppe, S., Breitling, S., Fitzner, S. (Eds.), Virtual Palaces II: Lost Palaces and Their Afterlife. Virtual Reconstruction Between Science and Media. Proceedings of the European Science Foundation Research Networking Programme PALATIUM meeting at Munich, 13.- 15. 4. 2012.

Grellert, M., Pfarr-Harfst, M., Kuroczyński, P., Münster, S., 2015. Virtual Reconstruction and Scientific/Academic 3D Models - Fundamental Considerations (lecture). 43rd Computer Applications and Quantitative Methods in Archaeology Conference 2015 Sienna.

Günther, H., 2001. Kritische Computer-Visualisierung in der kunsthistorischen Lehre, in: Frings, M. (Ed.), Der Modelle Tugend. CAD und die neuen Räume der Kunstgeschichte, Weimar, pp. 111-122.

Hauck, O., Kuroczyński, P., 2014. Cultural Heritage Markup Language - How to Record and Preserve 3D Assets of Digital Reconstruction, CHNT 19, Vienna http://chml.foundation/wpcontent/uploads/2015/06/CHNT19_Hauck_Kuroczynski.pdf (09.07.2015).

Havemann, S., Wagener, O., in print. Castles and their Landscape - A case study towards parametric historic reconstruction, in: Hoppe, S., Breitling, S., Fitzner, S. (Eds.), Virtual Palaces II: Lost Palaces and Their Afterlife. Virtual Reconstruction Between Science and Media. Proceedings of the European Science Foundation Research Networking Programme PALATIUM meeting at Munich, 13.- 15. 4. 2012.

Homann, G., 2011. Die Anwendung von Ontologien zur Wissensrepräsentation und -kommunikation im Bereich des kulturellen Erbes, in: Schomburg, S., Leggewie, C., Lobin, H., Puschmann, C. (Eds.), Digitale Wissenschaft - Stand und Entwickung digital vernetzter Forschung in Deutschland HBZ, Köln pp. 33-40.

Hoppe, S., 2001. Die Fußnoten des Modells, in: Frings, M. (Ed.), Der Modelle Tugend. CAD und die neuen Räume der Kunstgeschichte, Weimar, pp. 87-102.

Kiouss, A., Karoglou, M., Labropoulos, K., Moropoulou, A., Zarnic, R., 2011. Recommendations and Strategies for the Establishment of a Guideline for Monument Documentation Harmonized with the existing European Standards and Codes, XXIII CIPA Symposium - Proceedings.

Kröber, C., Münster, S., 2014. An App for the Cathedral in Freiberg - An Interdisciplinary Project Seminar, in: Sampson, D.G., Spector, J.M., Ifenthaler, D., Isaias, P. (Eds.), Proceedings of the 11th International Conference on cognition and 
exploratory learning in digital age (CELDA 2014) Porto, Portugal. Oct. 25-27th 2014, pp. 270-274.

Kuroczyński, P., 2012. 3D-Computer-Rekonstruktion der Baugeschichte Breslaus. Ein Erfahrungsbericht, in: Wissenschaften, W.Z.d.P.A.d. (Ed.), Jahrbuch des Wissenschaftlichen Zentrums der Polnischen Akademie der Wissenschaften in Wien, Band 3, Wien, pp. 201-213.

Kuroczyński, P., Hauck, O., Dworak, D., submitted paper. Digital Reconstruction of Cultural Heritage - Questions of documentation and visualisation standards for 3D content, EUROMED 2014.

Kuroczyński, P., Hauck, O., Dworak, D., Lutteroth, J., 2015. Virtual Museum of destroyed Cultural Heritage - 3D Documentation, reconstruction and visualisation in the Semantic Web, Proceedings of the 2nd International Conference "Virtual Archeology - Methods and benefits". The State Hermitage Publishers, St. Petersburg, pp. 54-61.

Kuroczyński, P., Pfarr-Harfst, M., Wacker, M., Münster, S., Henze, F., 2014. Pecha Kucha "Virtuelle Rekonstruktion Allgemeine Standards, Methodik und Dokumentation" (Panel), 1. Jahrestagung der Digital Humanities im deutschsprachigen Raum (DHd 2014), Passau.

Laufer, E., Lengyel, D., Pirson, F., Stappmanns, V., Toulouse, C., 2011. Die Wiederentstehung Pergamons als virtuelles Stadtmodell, in: Scholl, A., Kästner, V., Grüssinger, R. (Eds.), Pergamon. Panorama der antiken Metropole. Verlag Imhof, Petersberg, pp. 82-86.

Lengyel, D., Toulouse, C., 2011a. Darstellung von unscharfem Wissen in der Rekonstruktion historischer Bauten, in: Heine, K., Rheidt, K., Henze, F., Riedel, A. (Eds.), Von Handaufmaß bis High Tech III. 3D in der historischen Bauforschung. Verlag Philipp von Zabern, Darmstadt, pp. 182-186.

Lengyel, D., Toulouse, C., 2011b. Die Gestaltung der Vision Naga - Designing Naga's Vision,, in: Kröper, K., Schoske, S., Wildung, D. (Eds.), Königsstadt Naga - Naga, Royal City. Grabungen in der Wüste des Sudan - Excavations in the Desert of the Sudan. Naga-Projekt Berlin - Staatliches Museum Ägyptischer Kunst München, München, pp. 163-175.

Lengyel, D., Toulouse, C., 2011c. Ein Stadtmodell von Pergamon - Unschärfe als Methode für Darstellung und Rekonstruktion antiker Architektur, in: Petersen, L., Hoff, R.v.d. (Eds.), Skulpturen in Pergamon - Gymnasion, Heiligtum, Palast. Archäologische Sammlung der Albert-LudwigsUniversität Freiburg, Freiburg, pp. 22-26.

Lengyel, D., Toulouse, C., 2013. Die Bauphasen des Kölner Domes und seiner Vorgängerbauten: Gestaltung zwischen Architektur und Diagrammatik, in: Boschung, D., Jachman, J. (Eds.), Diagrammatik der Architektur, Tagungsband Internationales Kolleg Morphomata der Universität zu Köln. Verlag Wilhelm Fink, Paderborn, pp. 182-186.

Ling, Z., Ruoming, S., Keqin, Z., 2007. Rule-based 3d modeling for chinese traditional architecture in: Remondino, F., El-Hakim, S. (Eds.), 3D-ARCH 2007, Zürich.
Münster, S., 2011. Militärgeschichte aus der digitalen Retorte Computergenerierte 3D-Visualisierung als Filmtechnik, in: Kästner, A., Mazerath, J. (Eds.), Mehr als Krieg und Leidenschaft. Die filmische Darstellung von Militär und Gesellschaft der Frühen Neuzeit (Militär und Gesellschaft in der frühen Neuzeit, 2011/2), Potsdam, pp. 457-486.

Münster, S., 2013. Workflows and the role of images for a virtual 3D reconstruction of no longer extant historic objects. ISPRS Annals of the Photogrammetry, Remote Sensing and Spatial Information Sciences XL-5/W2 (XXIV International CIPA Symposium), 197-202.

Münster, S., Köhler, T., 2012. 3D modeling as tool for the reconstruction and visualization of "lost" buildings in humanities. A literature-based survey of recent projects (lecture), in: Hoppe, S., Breitling, S., Fitzner, S. (Eds.), Virtual Palaces II: Lost Palaces and Their Afterlife. Virtual Reconstruction Between Science and Media.European Science Foundation Research Networking Programme PALATIUM meeting at Munich, 13.- 15. 4. 2012.

Münster, S., Köhler, T., Hoppe, S., in print. 3D modeling technologies as tools for the reconstruction and visualization of historic items in humanities. A literature-based survey, in: Traviglia, A. (Ed.), Across Space and Time. Selected Papers from the 41st Computer Applications and Quantitative Methods in Archaeology Conference (Perth, 25.- 28. 3. 2013).

Münster, S., Prechtel, N., 2014. Beyond Software. Design Implications for Virtual Libraries and Platforms for Cultural Heritage from Practical Findings, in: Ioannides, M., MagnenatThalmann, N., Fink, E., Žarnić, R., Yen, A.-Y., Quak, E. (Eds.), Digital Heritage. Progress in Cultural Heritage: Documentation, Preservation, and Protection. Springer International Publishing Switzerland, Cham, pp. 131-145.

Niccolucci, F., 2012. Setting Standards for 3D Visualization of Cultural Heritage in Europe and Beyond, in: Bentkowska-Kafel, A., Denard, H., Baker, D. (Eds.), Paradata and Transparency in Virtual Heritage. Ashgate, Burlington, pp. 23-36.

Pfarr-Harfst, M., 2011. Documentation system for digital reconstructions. Reference to the Mausoleum of the TangDynastie at Zhaoling, in Shaanxi Province, China, 16th International Conference on "Cultural Heritage and New Technologies” Vienna, 2011, Wien, pp. 648-658.

Pfarr-Harfst, M., 2013. Virtual Scientific Models, in: Ng, K., Bowen, J.P., McDaid, S. (Eds.), Electronic Visualisation and the Arts, London, pp. 157-163.

Pfarr-Harfst, M., in print. 25 Years of Experience in Virtual Reconstructions - Research Projects, Status Quo of Current Research and Visions for the Future, in: Verhagen, P. (Ed.), Across Space and Time. Proceedings of the 42th International Conference on Computer Applications and Quantitative Methods in Archaeology (CAA). Archelingua, Budapest.

Pfarr, M., 2009. Dokumentationssystem für Digitale Rekonstruktionen am Beispiel der Grabanlage Zhaoling, Provinz Shaanxi, China (Dissertation), Darmstadt. 
Raspe, M., Schelbert, G., 2009. ZUCCARO - Ein Informationssystem für die historischen Wissenschaften. IT Information Technology 4, 207-215.

Riedel, A., Henze, F., Marbs, A., 2011. Paradigmenwechsel in der historischen Bauforschung? Ansätze für eine effektive Nutzung von 3D-Informationen, in: Heine, K., Rheidt, K., Henze, F., Riedel, A. (Eds.), Von Handaufmaß bis High Tech III - 3D in der historischen Bauforschung. Philipp von Zabern, Darmstadt, pp. 131-141.

Ronzino, P., 2015. CIDOC CRMBA - A CRM Extension for Buildings Archaeology Information Modeling (PhD-Thesis). The Cyprus Institute, Nicosia.

Ronzino, P., Amico, N., Niccolucci, F., 2011. Assessment and Comparison of Metadata Schemas for Architectural Heritage, XXIII CIPA Symposium - Proceedings.

Ronzino, P., Niccolucci, F., D’Andrea, A., 2013. Built Heritage metadate schemas and the integration of architectural datasets using CIDOC-CRM, in: Boriani, M., Gabaglio, R., Gulotta, D. (Eds.), Online Proceedings of the Conference BUILT HERITAGE 2013 Monitoring Conservation and Management, Milano, pp. 883-889.

Sürül, A., Özen, H., Tutkun, M., 2003. ICOMOS digital database of the Cultural Heritage of Trabzon. XIX CIPA Symposium - Proceedings.

Vorstand des Verbandes Digital Humanities im deutschsprachigen Raum, 2014. Digital Humanities 2020, Passau. 